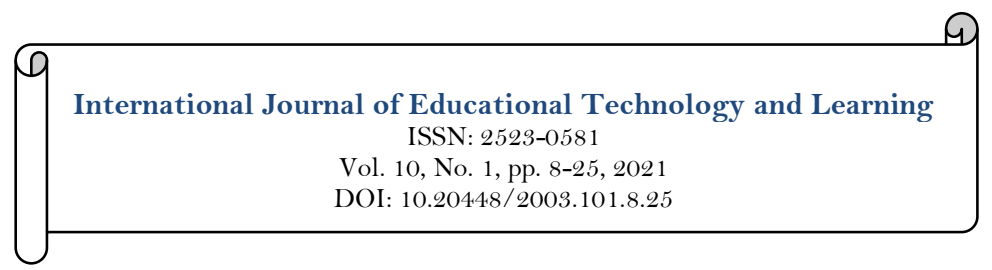

\title{
How to Promote Personal Financial Education - Findings from Finnish University Students' Financial Literacy Study
}

\author{
Sirli Mandmaa \\ Lappeenranta-Lahti University of Technology LUT Yliopistonkatu, Lappeenranta, Finland. \\ Email:sirlimandmaa@taltech.ee
}

\begin{tabular}{|c|c|}
\hline stract & \\
\hline $\begin{array}{l}\text { The results of The Organization for Economic Co-operation and } \\
\text { Development (OECD) and several studies show that the current level of } \\
\text { financial literacy of the population can guarantee sustainability neither for } \\
\text { them nor for society. As the financial crises and the situation during the } \\
\text { COVID-19 pandemic have demonstrated, people have difficulty coping even } \\
\text { with short-term income losses. This highlights the need to raise the level of } \\
\text { financial literacy, which requires promotion of personal financial education, } \\
\text { and specifically, -results from research. This paper presents the results from } \\
\text { the first financial literacy survey in Finland that was organized among } \\
\text { higher education students. The aim of the study was to assess the financial } \\
\text { literacy and compare the results with similar studies to identify bottlenecks } \\
\text { that could be improved through the promotion of financial education. The } \\
\text { results of the survey showed a good level of students'financial knowledge, but } \\
\text { also pointed out topics where the level of knowledge was low - areas like } \\
\text { insurance and interest rate changes. The results indicated that financial } \\
\text { literacy scores of students in mathematics-based academic disciplines are } \\
\text { significantly better than those of students in non-numerical disciplines. A } \\
\text { positive link was found between long-term planning and higher levels of } \\
\text { financial literacy. }\end{array}$ & $\begin{array}{l}\text { Licensed: } \\
\text { This work is licensed under a } \\
\text { Creative Commons Attribution } 4.0 \\
\text { License. } \\
\text { Publisher: } \\
\text { Scientific Publishing Institute }\end{array}$ \\
\hline
\end{tabular}

Funding: This study received no specific financial support.

Competing Interests: The author declares that there are no conflicts of interests regarding the publication of this paper. Acknowledgement: The author would like to thank academic staff and students from Lappeenranta University of Technology and Tampere University of Technology for their great assistance in data collection.

\section{Introduction}

Understanding financial literacy among young people is of critical importance for policymakers in several areas; it can aid those who wish to devise effective financial education programs targeted at young people as well as those writing legislations to protect younger consumers (Lusardi, Mitchell, \& Curto, 2010).

Researchers have examined the financial literacy and practice of various components of society and found out that financial knowledge needs improvement. Surveys throughout the world have shown that females tend to display lower level on personal financial literacy than males. In 2002, Chen and Volpe have argued that Personal Finance is mostly a number-oriented subject and not very attractive to women, as women prefer courses with less mathematics and other number-oriented science.

For improvement of financial literacy it is essential to enhance personal financial education.

Financial literacy is a combination of awareness, knowledge, skill, attitude, and behaviour necessary to make sound financial decisions and ultimately achieve individual financial wellbeing, according to the definition used by Organization for Economic Co-operation and Development (Atkinson \& Messy, 2012). 
The definition used in an international study to assess the financial literacy of young people is more specific: "Financial literacy is knowledge and understanding of financial concepts and risks, and the skills, motivation and confidence to apply such knowledge and understanding in order to make effective decisions across a range of financial contexts, to improve the financial well-being of individuals and society, and to enable participation in economic life." (OECD, 2014).

"Financial education is the process by which financial consumers/ investors improve their understanding of financial products and concepts and, through information, instruction and/or objective advice, develop the skills and confidence to become aware of (financial) risks and opportunities, to make informed choices, to know where to go for help, and to take other effective actions to improve their financial well-being and protection (OECD, 2006).

This paper presents the results from the first financial literacy survey in Finland that was organized to assess university students' financial literacy. An earlier study conducted in 2014 in Finland focused on financial literacy of a sample including respondents aged from 18 to 92. The OECD questionnaire (Atkinson \& Messy, 2012) formed the basis of the Finnish questionnaire that was supplemented with four questions. The researchers reported that the overall level of financial literacy in Finland was relatively high, though it was unequally distributed, as some groups (e.g., the elderly, women, and the less educated) had clearly lower levels of financial literacy. Furthermore, the results showed a positive and statistically significant connection between planning for retirement and financial literacy (Kalmi \& Ruuskanen, 2018).

Finns' educational level is high, which is evidenced in the PISA surveys (Average Score of PISA 2015 Mathematics, Science and Reading - 522.7 and position 8: PISA 2018 Mathematics, Science and Reading 516.3 and position 10. FactsMaps (n.d) and the levels of social security are high as well.

Accordingly, it is not surprising that students' financial literacy is good. However, the financial sector is developing and changing rapidly, which inevitably requires skills of individuals to possess and use knowledge to ensure smooth everyday life.

This study focused on two tasks:

1. To evaluate the financial literacy of students from universities of technology by highlighting differences between female and male students' levels.

2. To determine factors and obstructions having an impact on students' financial knowledge to contribute to the promotion of personal financial education.

The main goal of this study was to find out the needs and gaps in financial education using the assessment and comparison of students' financial literacy to develop the field.

In this study the financial literacy was assessed, and many factors were explored to see if they have the influence on students' financial literacy. The findings were compared with the results of studies conducted in Finland and in other countries to identify similarities or differences that would in current circumstances contribute to a better understanding of significance of the factors influencing financial literacy, in purpose to elaborate the personal financial education.

The selection of objects to study relied on the following deliberation:

Students are the next economically active population and creators of the future families, as well as the most promising segment to use financial services in the future due to better jobs, higher positions, and higher salaries. Students from universities of technology were chosen because of mathematics-based orientation. The sample contained $81 \%$ of students majoring in Engineering Science and $12 \%$ in Business.

This study gives the unique contributions to the literature by presenting the comparisons of financial knowledge between university students, who were coming from two related nations - Estonians and Finns but had a different recent history. Although the students in the same academic disciplines, i.e., in the current case, in the mathematics-based technological disciplines, revealed gender differences in financial knowledge.

Findings of this study suggest that Finnish students' financial literacy level is medium (statistically significant mean percentage of correct responses $73.5 \%$ ) and male students have slightly higher scores than female students. According to the survey, in some areas in participants' financial knowledge, the scores are at low level. Furthermore, the results showed the positive influence of mathematics skills and a positive statistically significant connection between the financial planning period and financial literacy.

The paper is organized as follows. Section 2 reviews previous studies related to financial literacy and education. Section 3 describes the methodology and the used data. Section 4 presents the obtained results, and Section 5 concludes the paper.

\section{Literature Review}

The findings from an OECD International Network on Financial Education pilot study undertaken in 14 countries showed a lack of financial knowledge amongst a sizable proportion of the population; in each of the countries surveyed, compound interest and diversification were the weakest topics (Atkinson \& Messy, 2012).

The findings from that pilot study highlighted that a significant proportion of the population in every country (at least 30\%) could benefit from additional financial knowledge. Compound interest and diversification were pointed out as the weakest topics in financial knowledge. (Atkinson \& Messy, 2012). 
Several studies throughout the world have shown that females tend to display lower level on personal financial literacy than males among adults (Atkinson \& Messy, 2012; Bucher-Koenen \& Lusardi, 2011; BucherKoenen, Lusardi, Alesi, \& Van Rooij, 2017; Fonseca, Mullen, Zamarro, \& Zissimopoulos, 2012; Kalmi \& Ruuskanen, 2018; Lusardi \& Mitchell, 2006; Monticone, 2010), students (Chen \& Volpe, 1998; Chen \& Volpe, 2002; Mändmaa, 2019a; Mändmaa, 2019b) and adolescents (Lusardi et al., 2010). Goldsmith and Goldsmith (1997); Goldsmith and Goldsmith (2006) suggested that females have lower level in financial literacy than males as their general interest in investment and personal finance is usually lower, and they are less confident in their ability to perform financial analysis. Following the same line of reasoning.

Atkinson, McKay, Kempson, and Collard (2006) pointed out that girls tend to gain lower grades than boys in mathematics at school, and perhaps have lower levels of confidence in certain areas of financial literacy. It could also be related to traditional roles within the home, with men being delegated the task of keeping informed. Chen and Volpe (2002) found that women generally have not only less knowledge about personal finance, but also have less enthusiasm for, and less willingness to learn about personal finance topics than men do. They argued that enthusiasm and confidence may be the contributing factors that explain why men are more financially knowledgeable than women (Chen \& Volpe, 2002). Fonseca et al. (2012) pointed out that women tend to live longer than men, have shorter work tenures, lower earnings and levels of pension or survivors' benefits, which places them at higher risk of having financial problems.

However, the surveys conducted among university students in Turkey (Altintas, 2011) and in Estonia (Mändmaa, 2020a; Mändmaa, 2020b) showed that female students have higher scores in financial literacy than men.

Understanding how and why men and women have different levels of financial literacy allow us to develop policies aimed at reducing the gender gap and improving the saving and investing decisions.

There are a number of studies in different parts of the world (Chen \& Volpe, 1998; Mandell, 2008; Mändmaa, 2019a; Mändmaa, 2019b; Pires \& Quelhas, 2015) that have examined students' financial knowledge and have revealed that students in an economic academic discipline or individuals attending programs in business sciences tend to exhibit a higher level of financial literacy. Lewis Mandell who has surveyed the financial literacy of young American adults expressed the following opinion: " Regardless of major, college students learn how to do research and solve problems. In a rapidly changing financial system, these two skills are more important to financial decision-making than understanding financial products, rules, and regulations. Knowing how to approach a problem and how to research it are key to making the best personal financial decisions." (2008, p. 29) According to the results, students majoring in science and engineering had the highest financial literacy scores and those majoring in business or economics came next (Mandell, 2008). Mändmaa (2020a) has reported similar results by surveying Estonian students majoring in engineering sciences.

Researchers have found (Mändmaa, 2020b; Pires \& Quelhas, 2015) that the existence of prior experience, such as credit clients or the existence of saving habits, increases the financial literacy of individuals.

Previous research has found that people with low financial literacy are more likely to have problems with debt (Lusardi \& Tufano, 2009) and are less likely to plan for retirement (Lusardi \& Mitchell, 2006).

Between 1997 and 2007, the financial situation of young people in USA was characterized increasingly by high levels of debt, as average undergraduate student loan debt increased by $58 \%$ after accounting for inflation Reed (2008). Cole, Paulson, and Shastry (2012) showed that education improves credit scores, and dramatically reduces the probability of declaring bankruptcy, as well as significantly increases investment income and retirement savings.

Wealthy people are more financially literate than poor people, and those with high education attainment are also more financially literate (Lusardi, 2017).

\section{Methodology}

This study uses a standardized survey method of data collection. The questionnaire is designed to cover major aspects of personal finance and includes the topics about general knowledge of personal finance, saving, borrowing, investment, and insurance. This survey uses multiple-choice questions, including 10 questions on demographic data, 22 questions to measure financial literacy and six questions to clarify financial opinions and choices. The questions were chosen similar to those of surveys conducted in a number of other countries, which enables comparisons within the country and cross-country. The issues vary in difficulty, although none of them is excessively complex nor requires expert knowledge.

The questions originate mainly from approved financial literacy questionnaires.

Eight questions have been selected from the questionnaire used by Chen and Volpe (1998) to assess US students' financial literacy and have been later used in a few studies. The questions from "A simple financial literacy module", which has been designed in 2004 for the American Health and Retirement Study (HRS) by Lusardi and Mitchell (2011) have been included (three questions, with one small correction) to the current study. These three questions have proved effective in measuring knowledge of simple but fundamental financial decision-making concepts. Two of them have been used in the OECD 2012 study questionnaire, which comprises good practice questions drawn from existing financial literacy questionnaires (Atkinson \& Messy, 2012). The present survey used seven questions of eight possible from the OECD 2012 questionnaire. 
Since participants from universities of technology have high level of knowledge in mathematics, the question about division (Question no. 1 in OECD 2012 knowledge questions) was omitted.

The validity and clarity of the survey were previously evaluated by a group of master level students and by three experts knowledgeable in personal finance topics.

The polls were conducted during the lectures in the paper form. That form was chosen because internetor mail-based surveys might provide the respondents with an opportunity to improve their knowledge, thereby overstating their true knowledge; in addition, that form supported the increase of participant number. The respondents answered anonymously and as they did not need to worry about confidentiality, the responses could be more reliable.

The responses from each participant were used to calculate the mean percentage of correct scores for each question and the entire survey, and also for calculating the median, to assess the level of financial literacy and to analyze the results. Consistent with the existing literature (Chen \& Volpe, 1998; Mändmaa, 2019a; Mändmaa, 2019b) the mean percentage of correct scores was grouped into three categories. The first category represents a relatively high level (more than $80 \%$ ) of knowledge, the second a medium (60\% to $79 \%$ ) and the third represents a relatively low level (below 60\%) of knowledge. In addition, analysis of variance (ANOVA) was used to determine the differences in personal financial literacy between male and female students.

Based on previous studies (Bucher-Koenen et al., 2017; Kalmi \& Ruuskanen, 2018) for the questions from "A simple financial literacy module", additional scores about correct answers were calculated to enable better comparison of the results.

Previous researchers suggested that levels of financial literacy vary among subgroups of students (Chen \& Volpe, 1998; Chen \& Volpe, 2002; Mändmaa, 2019a; Mändmaa, 2019b). The ANOVA tests were used to provide evidence of the differences. The differences were further analysed using logistic regression models. The participants were divided into two groups using the median percentage of correct answers for the entire survey. Students with scores higher than the median were classified as students with relatively high level (More) of knowledge, coded as "1" and students with scores equal or below the median were classified as those with relatively low level (Less) of knowledge, coded as "o". The dichotomous variable, financial literacy level (More, Less), was used in logistic regression as the dependent variable, which was explained by independent variables. The logistic regression analysis was conducted separately for three times (1. entire sample; 2 . male participants; 3. female participants) to detect if the independent variables have different effects on participants' financial literacy. The independent variables (picked from Table 3, Table 4, and Table 5) used in this analyse included participants' academic discipline, level of education, age, work experience, gender, household size, personal monthly income, parents' educational level, amount of books in childhood home, currently available financial services, including using the credit card, and interest in the personal finance topics. In this study, the logistic model has the following functional form:

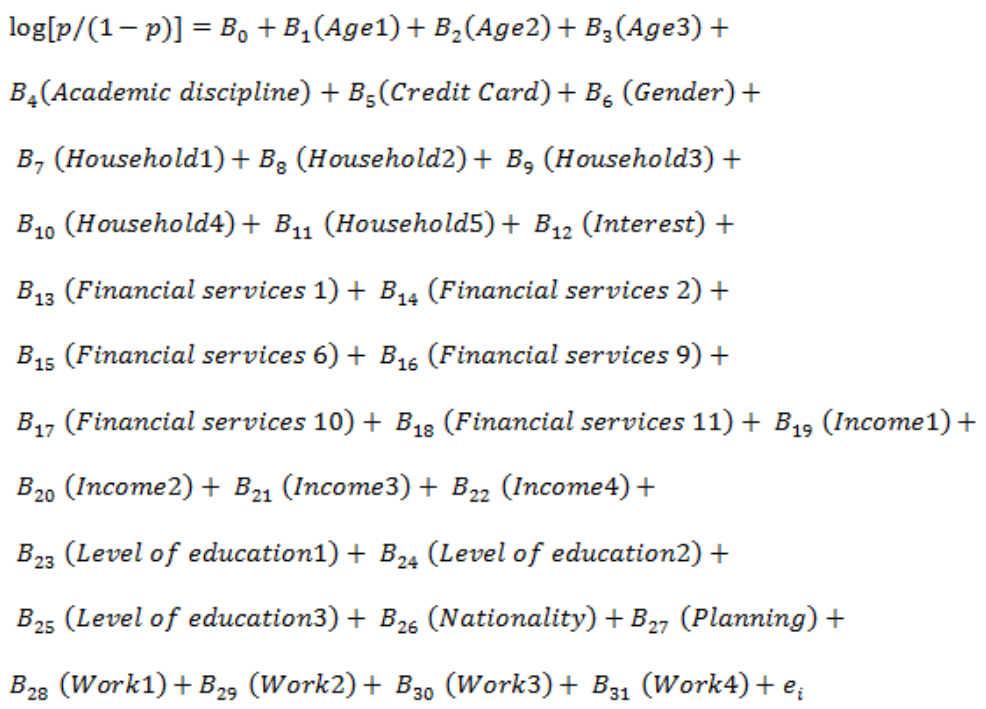

where: $\mathrm{p}=$ the probability of a participant with relatively more knowledge about personal finance; $\mathrm{B}=$ the coefficient. Coefficients $B_{1}$ to $B_{31}$ represent the effect of each subgroup.

For the sake of comparability of the results, in this study, the same questionnaire and the functional form of the logistic model (1) used in the study conducted by Mändmaa (2020b) among Estonian students were used. males.

Researchers throughout the world have reported that females have lower level in financial literacy than 
Table-1. Characteristics of the sample.

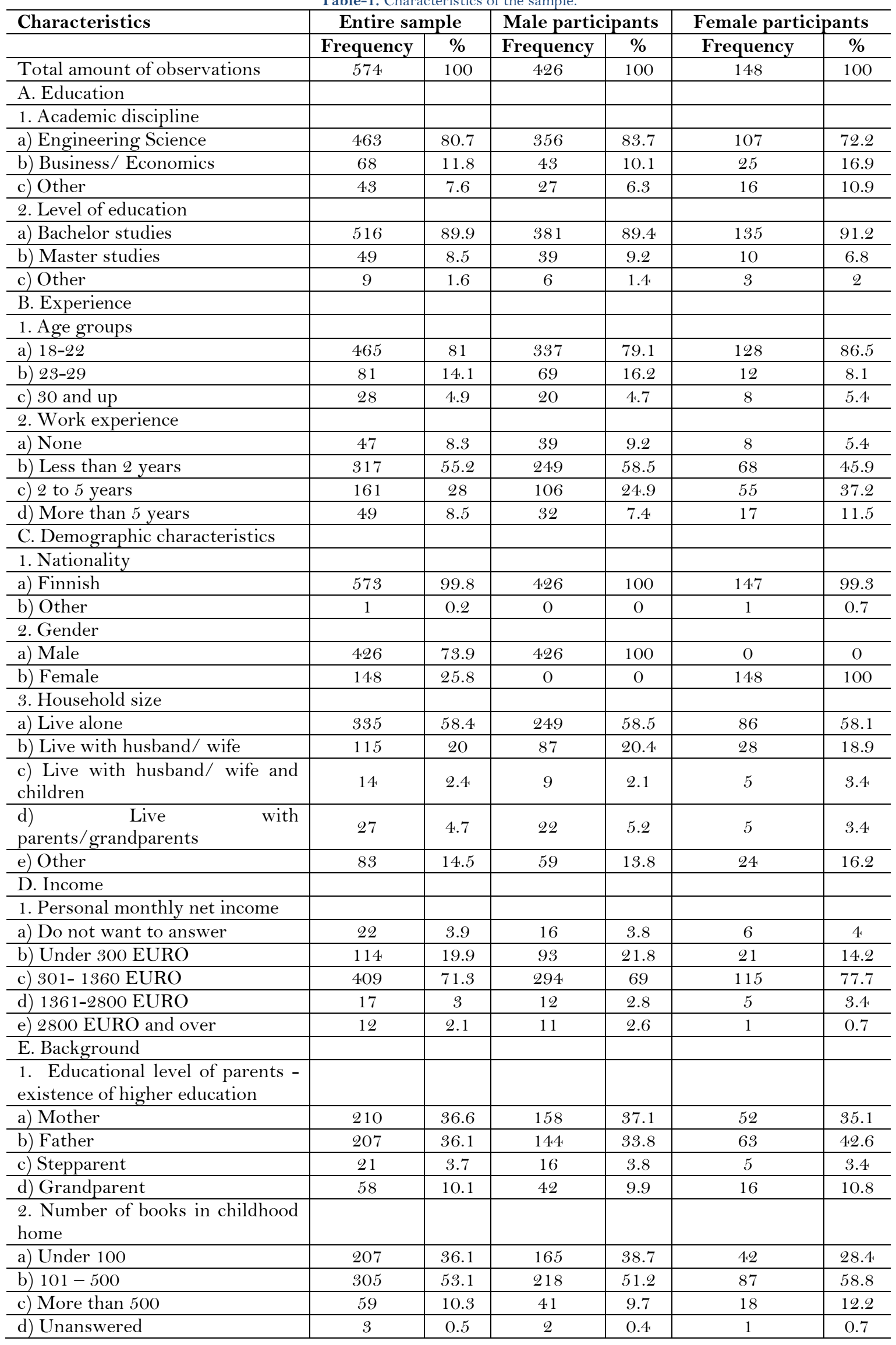


To understand and find some evidence if financial education should be taught to male and female students differently, in addition, students' choices (financial planning and services using) were analyzed. The relationships between students' choices, financial literacy and socio-demographic background were described using the Cross-tabulations, Chi-square tests, descriptive statistics, and analysis of variances (ANOVA).

Data were collected from two universities of technology based on convenience sampling in purpose to achieve comparability of data with survey conducted among Estonian students.

The size of the sample used in the evaluation of students' financial literacy was 574 (426 male and 148 female students). In the survey, students from two Finnish universities participated: 321 (250 male and 71 female) students from Tampere University of Technology and 253 (176 male and 77 female) students from Lappeenranta University of Technology. The characteristics of the sample of the Finnish students' financial literacy study are presented in Table 1 . In the further analyses, the missing responses caused the sample size to vary from 522 to 573 and therefore, different sample sizes were used to calculate valid percentages in Tables 4 and 5 .

In the comparisons, the data from the study conducted among the students in Tallinn University of Technology in 2015 and partly from the study among Estonian university students in higher educational institutions in 2012 were used. The sample sizes were respectively 536 (326 male and 210 female students) and 522 (204 male and 318 female students). More specific information about these two studies is reported by Mändmaa (2020a); Mändmaa (2020b).

\section{Results and Analysis}

In this section, the results from the survey of students at higher education institutions in Finland are presented. The survey was conducted to evaluate the level of financial literacy and analyze the factors influencing students' financial knowledge. The questionnaire was filled in by 574 students. About $95 \%$ of the students were from 18 to 29 years of age. In terms of gender, male participants accounted for about $74 \%$ and females $26 \%$ of the sample.

The collected data were analyzed using the software Statistical Package for the Social Sciences (SPSS).

\subsection{Differences in Personal Financial Literacy}

The survey responses are summarized and differences of answers by gender and by the level of financial literacy are presented in Table 2. Lower financial literacy scores mainly concerned topics of insurance, development of interest, and loan co-sing consequences. In total, survey results showed that participants' financial literacy was at medium level - an average score of correct answers was $74 \%$. Female students answered to $72 \%$ of the questions correctly, and male students had correct answers for $74 \%$ of questions.

Answers to questions from "A simple financial literacy module" were compared separately with responses from earlier studies and the results are presented in Table 7.

\subsection{Analysis of Results by Subgroups of the Sample}

The results in the previous section displayed the differences in students' financial literacy based on gender, but the effects of other determining factors were not addressed. In this section, the relationship between the personal financial literacy level and the characteristics of the sample was examined Table 3 . The ANOVA was used to detect if factors from various subgroups had different effect on the level.

The ANOVA results showed that not many significant differences exist in the current sample. Findings admitted gender differences and differences in financial knowledge in the subgroup of personal monthly net income. The financial literacy level showed a rise with income, except the cases where the income was over 2800 euros per month. The nationality characteristic had also a significant value of $\mathrm{F}$-statistic, but that was treated as an exception, as there was only one non-Finnish female student who probably had poor language skills, i.e., she did not understand the questions correctly. Based on the F-statistic values, there were no significant differences in the subgroup of background (level of education of the parents and number of books in childhood home).

\subsection{Analysis of Results by Participants' Choices}

This section analyzes participants' choices about using the financial services. The results showed that $98 \%$ of the participants had Current Account, 91\% Debit Card; 61\% Saving Account, 58\% Insurance Services, 38\% Student Loan, $27 \%$ Investment Services, and $17 \%$ of the participants were Credit Card owners.

Analysis of variance was used to detect if participants with different choices of using financial services had different levels of financial knowledge. Based on earlier studies (Mändmaa, 2020a; Mändmaa, 2020b; Pires \& Quelhas, 2015) the use of financial services has an impact on students' financial literacy. In general, the participants with higher level of financial literacy used financial services more than participants with lower financial literacy level. Our findings showed that the following financial services had a statistically significant effect: Current Account, Debit Card, Insurance, and Investment Services. The results are presented in Table 4. No remarkable gender differences were found in the results, except in using investment services where the differences in female students' results were not statistically significant. 
Table-2. Mean percentages of correct responses by gender and results of ANOVA.

\begin{tabular}{|c|c|c|c|c|}
\hline & \multicolumn{4}{|c|}{ Level of Personal Financial Literacy } \\
\hline & Low & Medium & High & Total \\
\hline & Below $60 \%$ & $60-79 \%$ & Over $80 \%$ & $\%$ \\
\hline & $\begin{array}{lll} & \mathrm{F} & \mathrm{F} \text { test }\end{array}$ & $\begin{array}{lll}\text { M } & \text { F } & \text { F test }\end{array}$ & $\begin{array}{lll}\mathrm{M} & \mathrm{F} & \mathrm{F} \text { test }\end{array}$ & \\
\hline \multicolumn{5}{|c|}{ I General personal finance knowledge } \\
\hline $\begin{array}{l}\text { 1. Personal financial } \\
\text { literacy }\end{array}$ & & & $\begin{array}{lll}83.6 & 83.1 & 0.017 \\
\end{array}$ & 83.4 \\
\hline 2. Asset liquidity & & $\begin{array}{lll}66.9 & 55.4 & 6.343^{*} * * * *\end{array}$ & & 63.9 \\
\hline $\begin{array}{l}\text { 3. Definition of } \\
\text { inflation }\end{array}$ & & & $85.2 \quad 77.7 \quad 4.465^{* * *}$ & 83.3 \\
\hline $\begin{array}{l}\text { 4. Time-value of } \\
\text { money }\end{array}$ & & & $86.1 \quad 84.5 \quad 0.256$ & 85.7 \\
\hline $\begin{array}{l}\text { 5. Interest paid on a } \\
\text { loan }\end{array}$ & & & $89.2 \quad 92.6 \quad 1.390$ & 90.1 \\
\hline $\begin{array}{l}\text { 6. Legal requirement } \\
\text { for apartment lease }\end{array}$ & & $72.3 \quad 79.0 \quad 2.609^{*}$ & & 74 \\
\hline $\begin{array}{l}\text { 7. Change in the } \\
\text { purchasing power of } \\
\text { money }\end{array}$ & $\begin{array}{rrr}58.9 & 60.1 \quad 0.067 \\
\end{array}$ & & & 59.2 \\
\hline 8. Discount valuation & & & $\begin{array}{lll}99.1 & 99.3 & 0.088 \\
\end{array}$ & 99.1 \\
\hline $\begin{array}{l}\text { Mean correct } \\
\text { responses for the I } \\
\text { section }\end{array}$ & & $80.2 \quad 79.0 \quad 0.656$ & & 79.9 \\
\hline \multicolumn{5}{|c|}{ II Saving, borrowing, insurance and investments } \\
\hline $\begin{array}{l}\text { 9. Appropriate saving } \\
\text { place }\end{array}$ & & & $90.4 \quad 85.1 \quad 3.093^{*}$ & 89 \\
\hline $\begin{array}{l}\text { 10. Calculation of } \\
\text { interest plus principle }\end{array}$ & & & $90.1 \quad 93.9 \quad 1.936$ & 91.1 \\
\hline $\begin{array}{l}11 . \text { Compound } \\
\text { interest }\end{array}$ & & & $84.3 \quad 76.3 \quad 4.739 * *$ & 82.2 \\
\hline $\begin{array}{l}\text { 12. Purchasing power } \\
\text { assessment }\end{array}$ & & & $92.2 \quad 85.8 \quad 5.381^{* * *}$ & 90.6 \\
\hline $\begin{array}{l}\text { 13. Monthly payments } \\
\text { of mortgage }\end{array}$ & & $77.7 \quad 69.6 \quad 3.926^{* * *}$ & & 75.6 \\
\hline 14. Interest of loan & & $\begin{array}{lll}67.4 & 60.1 & 2.547^{*} \\
\end{array}$ & & 65.6 \\
\hline $\begin{array}{l}\text { 15. Loan co-sing } \\
\text { consequences }\end{array}$ & $\begin{array}{lll}39.4 & 40.5 & 0.056 \\
\end{array}$ & & & 39.7 \\
\hline $\begin{array}{l}\text { 16. The interest rate } \\
\text { evaluation }\end{array}$ & & & $\begin{array}{lll}96.5 & 96.6 & 0.007 \\
\end{array}$ & 96.5 \\
\hline $\begin{array}{l}\text { 17. Understanding the } \\
\text { content of insurance }\end{array}$ & & & $\begin{array}{llll}79.8 & 82.4 & 0.479 \\
\end{array}$ & 80.5 \\
\hline $\begin{array}{l}\text { 18. Homeowners' } \\
\text { insurance }\end{array}$ & $15.3 \quad 13.5 \quad 0.264$ & & & 14.8 \\
\hline $\begin{array}{l}\text { 19. Revenue of } \\
\text { different interest } \\
\text { calculation }\end{array}$ & $49.3 \quad 41.2 \quad 2.881^{*}$ & & & 47.2 \\
\hline 20. Diversification & & & $\begin{array}{lll}94.4 & 87.2 & 8.316^{*} \text { *** }\end{array}$ & 92.5 \\
\hline 21. Risk and return & & & $\begin{array}{lll}95.8 & 93.2 & 1.516\end{array}$ & 95.1 \\
\hline $\begin{array}{l}22 . \text { Interest rates } \\
\text { changes and treasury } \\
\text { bond price }\end{array}$ & $\begin{array}{lll}18.1 & 18.2 & 0.002 \\
\end{array}$ & & & 18.1 \\
\hline $\begin{array}{l}\text { Mean correct } \\
\text { responses for the II } \\
\text { section }\end{array}$ & & $70.6 \quad 67.4 \quad 7.744^{*}$ *** & & 69.9 \\
\hline $\begin{array}{l}\text { Mean correct } \\
\text { responses for the } \\
\text { entire survey }\end{array}$ & & $74.2 \quad 71.6 \quad 6.083^{*} * * *$ & & 73.5 \\
\hline Median correct respons & s for the entire survey & & & 77.3 \\
\hline
\end{tabular}


Table-3. Mean percentage of correct responses by characteristics of the sample and results of ANOVA.

\begin{tabular}{|c|c|c|c|c|}
\hline & Total count & Total \% & Male \% & Female \% \\
\hline \multicolumn{5}{|l|}{ A. Education } \\
\hline 1. Academic discipline & & 1.311 & 0.402 & 0.936 \\
\hline a) Engineering Science & 463 & 73.7 & 74.3 & 71.7 \\
\hline b) Business / Economics & 68 & 73.8 & 74.1 & 73.3 \\
\hline c) Other & 43 & 70.9 & 72.4 & 68.5 \\
\hline 2. Level of education & & 0.866 & 0.323 & 1.219 \\
\hline a) Bachelor studies & 516 & 73.5 & 74.1 & 71.9 \\
\hline b) Master studies & 49 & 74.4 & 75.4 & 70.4 \\
\hline c) Other & 9 & 69.2 & 72.7 & 62.1 \\
\hline \multicolumn{5}{|l|}{ B. Experience } \\
\hline 1. Age groups & & 1.086 & 0.749 & 1.397 \\
\hline a) $18-22$ & 465 & 73.3 & 73.9 & 71.8 \\
\hline b) $23-29$ & 81 & 73.6 & 74.6 & 67.4 \\
\hline c) 30 and up & 28 & 76.5 & 76.8 & 75.6 \\
\hline 2. Work experience & & 1.323 & 1.794 & 0.470 \\
\hline a) None & 47 & 71.6 & 70.9 & 75.0 \\
\hline b) Less than 2 years & 317 & 74.0 & 74.7 & 71.4 \\
\hline c) 2 to 5 years & 161 & 72.7 & 73.7 & 70.8 \\
\hline d) More than 5 years & 49 & 75.0 & 76.0 & 73.3 \\
\hline \multicolumn{5}{|l|}{ C. Demographic characteristics } \\
\hline 1. Nationality & & $6.69^{* * *}$ & - & $5.842^{*}$ \\
\hline a) Finnish & 573 & 73.6 & 74.2 & 71.8 \\
\hline b) Other & 1 & 45.4 & - & 45.4 \\
\hline (F Statistic) & & $6.083^{*} *$ & - & - \\
\hline a) Male & 426 & 74.2 & 74.2 & - \\
\hline b) Female & 148 & 71.6 & - & 71.8 \\
\hline 3. Household size & & 0.160 & 0.103 & 0.692 \\
\hline a) Live alone & 335 & 73.6 & 74.0 & 72.6 \\
\hline b) Live with husband/ wife & 115 & 72.8 & 74.2 & 68.7 \\
\hline c) Live with husband/ wife and children & 14 & 73.0 & 73.2 & 72.7 \\
\hline d) Live with parents/grandparents & 27 & 74.1 & 74.6 & 71,8 \\
\hline e) Other & 83 & 73.8 & 74.8 & 71,2 \\
\hline \multicolumn{5}{|l|}{ D. Income } \\
\hline $\begin{array}{l}\text { 1. Personal monthly net income } \\
(\mathrm{F} \text { Statistic })\end{array}$ & & $2.540^{*}$ & $2.808^{*}$ & 0.801 \\
\hline a) Do not want to answer & 22 & 72.3 & 73.8 & 68.2 \\
\hline b) Under 300 EURO & 114 & 71.2 & 71.2 & 71.2 \\
\hline c) 301- 1360 EURO & 409 & 74.0 & 74.9 & 71.7 \\
\hline d) 1361-2800 EURO & 17 & 78.6 & 79.2 & 77.3 \\
\hline e) 2800 EURO and over & 12 & 72.7 & 74.0 & 59.1 \\
\hline \multicolumn{5}{|l|}{ E. Background } \\
\hline \multicolumn{5}{|l|}{$\begin{array}{l}\text { 1. Educational level of parents - existence of } \\
\text { higher education }\end{array}$} \\
\hline (F Statistic) & 210 & $73.5(0.003)$ & $\begin{array}{c}74.7 \\
(0.681) \\
\end{array}$ & $69.9(1.893)$ \\
\hline (F Statistic) & 207 & $73.8(0.157)$ & $\begin{array}{c}74.5 \\
(0.225) \\
\end{array}$ & $72,0(0.132)$ \\
\hline c) Stepparent & 21 & $73.6(0.001)$ & $\begin{array}{c}75.0 \\
(0.096) \\
\end{array}$ & $69.1(0.271)$ \\
\hline d) Grandparent $\quad$ (F Statistic) & 58 & $75.3(1.747)$ & $\begin{array}{c}76.4 \\
(1.987)\end{array}$ & $72.4(0.099)$ \\
\hline $\begin{array}{l}\text { 2. Number of books in childhood home ( } \mathrm{F} \\
\text { Statistic) }\end{array}$ & & 0.309 & 0.722 & 0.090 \\
\hline a) Under 100 & 207 & 73.0 & 73.4 & 71.4 \\
\hline b) $101-500$ & 305 & 73.7 & 74.6 & 71.6 \\
\hline c) More than 500 & 59 & 74.3 & 75.4 & 71.7 \\
\hline d) Unanswered & 3 & 71.2 & 68.2 & 77.3 \\
\hline
\end{tabular}


Table-4. Mean percentage of correct responses by students' financial choices and results of ANOVA.

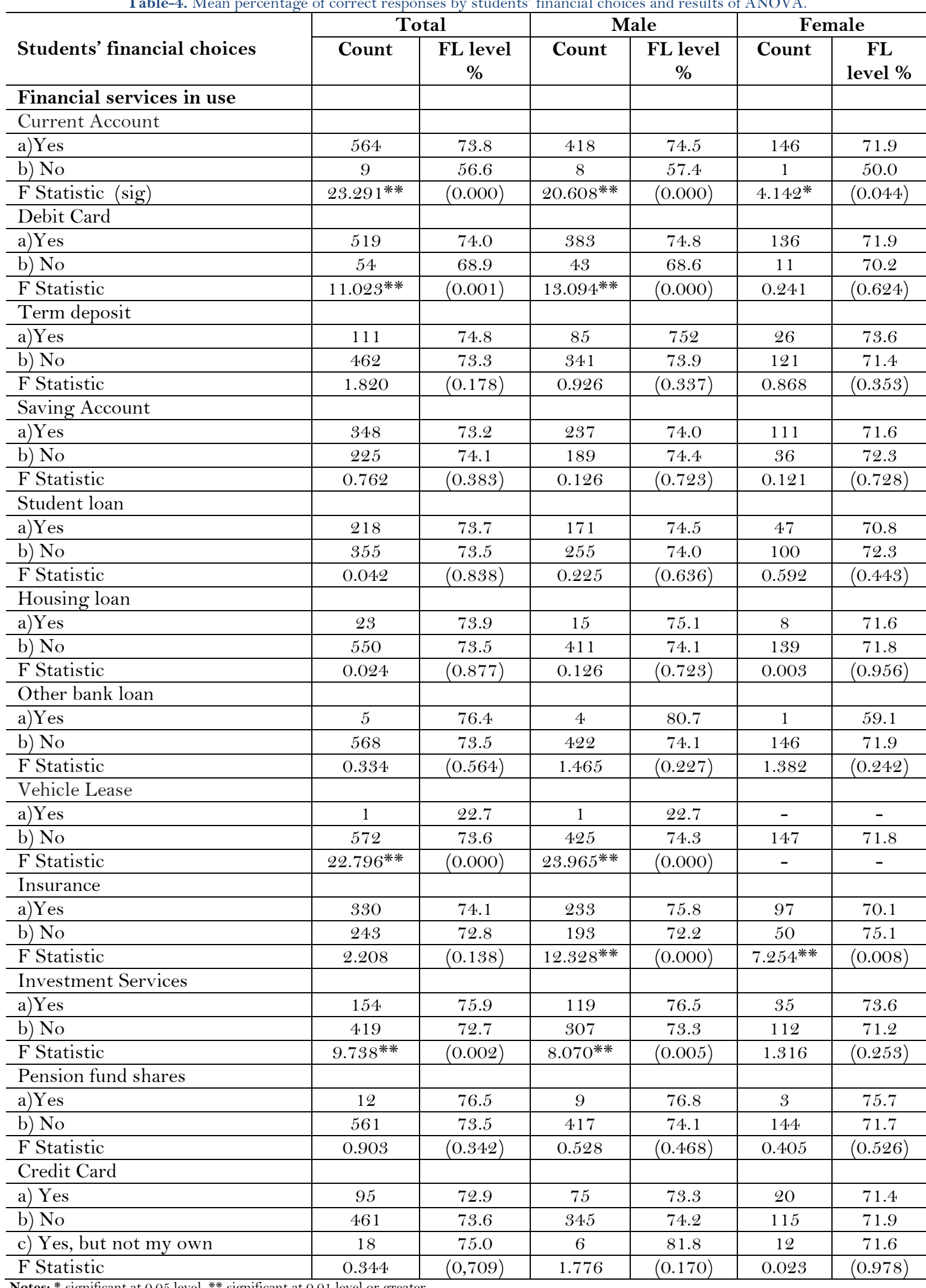

\subsection{Students' Financial Planning Habits}

In this section, the Cross-tabulations and Chi-square tests were used to show differences in students' financial affair planning habits. The results Table 5 showed that the most preferable planning period was one month, as $38 \%$ of students $(37 \%$ of males and $40 \%$ of females) picked that to answer the question: "How long in advance do you plan your financial affairs (the expected revenues, the necessary costs and predictable financial 
situation)?”. Statistically significant test results revealed that $13 \%$ of students planned their financial affairs to several years and less than $1 \%$ until retirement (that was only male student's choice). In terms of long-term planning, the higher financial literacy level generally was related to a longer planning period. The share of students' who do not see the need to plan was on average $3 \%$ ( $4.1 \%$ of males, $1.5 \%$ of females).

Table-5. Students' financial planning habits by financial literacy level and by gender.

\begin{tabular}{|c|c|c|c|c|c|c|}
\hline \multirow{2}{*}{$\begin{array}{l}\text { How long in advance do you } \\
\text { plan your financial affairs? }\end{array}$} & \multirow[t]{2}{*}{ Total } & \multicolumn{3}{|c|}{ Financial literacy level } & \multicolumn{2}{|c|}{ Gender } \\
\hline & & Low & Medium & High & Male & Female \\
\hline $\begin{array}{l}\text { do not see the need to plan } \\
\text { Count } \\
\text { \% within row } \\
\% \text { within column }\end{array}$ & $\begin{array}{c}18 \\
100.0 \\
3.4\end{array}$ & $\begin{array}{c}4 \\
22.2 \\
5.8\end{array}$ & $\begin{array}{c}9 \\
50.0 \\
3.2\end{array}$ & $\begin{array}{c}5 \\
27.8 \\
2.9\end{array}$ & $\begin{array}{c}16 \\
88.9 \\
4.1\end{array}$ & $\begin{array}{c}2 \\
11.1 \\
1.5\end{array}$ \\
\hline $\begin{array}{l}\text { on a current basis, on daily basis } \\
\text { Count } \\
\% \text { within row } \\
\% \text { within column }\end{array}$ & $\begin{array}{c}24 \\
1000 \\
4.6\end{array}$ & $\begin{array}{c}6 \\
25.0 \\
8.7\end{array}$ & $\begin{array}{c}13 \\
52.2 \\
4.7\end{array}$ & $\begin{array}{c}5 \\
20.8 \\
2.9\end{array}$ & $\begin{array}{c}15 \\
62.5 \\
3.8\end{array}$ & $\begin{array}{c}9 \\
37.5 \\
6.9\end{array}$ \\
\hline $\begin{array}{l}\text { weekly fortnightly } \\
\text { Count } \\
\text { \% within row } \\
\text { \% within column }\end{array}$ & $\begin{array}{c}48 \\
100.0 \\
9.2\end{array}$ & $\begin{array}{c}14 \\
29.2 \\
20.3\end{array}$ & $\begin{array}{c}17 \\
35.4 \\
6.1\end{array}$ & $\begin{array}{c}17 \\
35.4 \\
9.8\end{array}$ & $\begin{array}{c}34 \\
70.8 \\
8.7\end{array}$ & $\begin{array}{c}14 \\
29.2 \\
10.7\end{array}$ \\
\hline $\begin{array}{lll}\text { on a } & \text { monthly } & \text { basis } \\
\text { Count } & \\
\text { \% within row } & \\
\text { \% within column } & & \\
\end{array}$ & $\begin{array}{c}196 \\
100.0 \\
37.5\end{array}$ & $\begin{array}{c}22 \\
11.2 \\
31.9\end{array}$ & $\begin{array}{l}118 \\
60.2 \\
42.3\end{array}$ & $\begin{array}{c}56 \\
28.6 \\
32.2\end{array}$ & $\begin{array}{l}144 \\
73.5 \\
36.8\end{array}$ & $\begin{array}{c}52 \\
26.5 \\
39.7\end{array}$ \\
\hline $\begin{array}{l}\text { on a } \quad \text { 3-month basis } \\
\text { Count } \\
\text { \% within row } \\
\text { \% within column }\end{array}$ & $\begin{array}{c}47 \\
100.0 \\
9.0\end{array}$ & $\begin{array}{c}6 \\
12.8 \\
8.7\end{array}$ & $\begin{array}{c}25 \\
53.2 \\
9.0\end{array}$ & $\begin{array}{c}16 \\
34.0 \\
9.2\end{array}$ & $\begin{array}{c}35 \\
74.5 \\
9.0\end{array}$ & $\begin{array}{c}12 \\
25.5 \\
9.2\end{array}$ \\
\hline $\begin{array}{lll}\text { on a } & \text { 6-month } & \text { basis } \\
\text { Count } & & \\
\text { \% within row } & \\
\text { \% within column } & \\
\end{array}$ & $\begin{array}{c}57 \\
100.0 \\
10.9\end{array}$ & $\begin{array}{c}5 \\
8.8 \\
7.2\end{array}$ & $\begin{array}{c}32 \\
56.1 \\
11.5\end{array}$ & $\begin{array}{c}20 \\
35.1 \\
11.5\end{array}$ & $\begin{array}{c}44 \\
77.2 \\
11.3\end{array}$ & $\begin{array}{c}13 \\
22.8 \\
9.9\end{array}$ \\
\hline $\begin{array}{lll}\text { on } \quad \text { a } & \text { 1-year } & \text { basis } \\
\text { Count } & & \\
\text { \% within row } & & \\
\text { \% within column } & & \\
\end{array}$ & $\begin{array}{c}63 \\
100.0 \\
12.1\end{array}$ & $\begin{array}{c}6 \\
9.5 \\
8.7\end{array}$ & $\begin{array}{c}33 \\
52.4 \\
11.8\end{array}$ & $\begin{array}{c}24 \\
38.1 \\
13.8\end{array}$ & $\begin{array}{c}47 \\
74.6 \\
12.0\end{array}$ & $\begin{array}{c}16 \\
25.4 \\
12.2\end{array}$ \\
\hline $\begin{array}{lll}\text { on several } & \text { years } & \text { basis } \\
\text { Count } & & \\
\text { \% within row } & & \\
\text { \% within column } & & \\
\end{array}$ & $\begin{array}{c}65 \\
100.0 \\
12.5\end{array}$ & $\begin{array}{c}5 \\
7.7 \\
7.2\end{array}$ & $\begin{array}{c}29 \\
44.6 \\
10.4\end{array}$ & $\begin{array}{c}31 \\
47.7 \\
17.8\end{array}$ & $\begin{array}{c}52 \\
80.0 \\
13.3\end{array}$ & $\begin{array}{c}13 \\
20.0 \\
9.9\end{array}$ \\
\hline $\begin{array}{l}\text { until } \\
\text { Count } \\
\text { \% within row } \\
\text { \% within column }\end{array}$ & $\begin{array}{c}4 \\
100.0 \\
0.8\end{array}$ & $\begin{array}{c}1 \\
25.0 \\
1.4\end{array}$ & $\begin{array}{c}3 \\
75.0 \\
1.1\end{array}$ & $\begin{array}{l}\mathrm{O} \\
\mathrm{O} \\
\mathrm{O}\end{array}$ & $\begin{array}{c}4 \\
100.0 \\
1.0\end{array}$ & $\begin{array}{l}\mathrm{O} \\
\mathrm{O} \\
\mathrm{O}\end{array}$ \\
\hline $\begin{array}{l}\text { Total } \\
\text { Count } \\
\text { \% within row } \\
\% \text { within column }\end{array}$ & $\begin{array}{c}522 \\
100.0 \\
100.0\end{array}$ & $\begin{array}{c}69 \\
13.2 \\
100.0\end{array}$ & $\begin{array}{c}279 \\
53.4 \\
100.0\end{array}$ & $\begin{array}{c}174 \\
33.3 \\
100.0\end{array}$ & $\begin{array}{c}391 \\
74.9 \\
100.0\end{array}$ & $\begin{array}{c}131 \\
25.1 \\
100.0\end{array}$ \\
\hline Notes: & & $\begin{array}{r}\text { Chi-s } \\
\text { significan }\end{array}$ & $\begin{array}{l}=31.435 \\
\text { e } 0.012 \text { level }\end{array}$ & & $\begin{array}{l}\text { Chi-s } \\
\text { signific }\end{array}$ & $\begin{array}{l}\text { e }=6.880 \\
\text { the } 0.550 \\
\text { el }\end{array}$ \\
\hline
\end{tabular}

\subsection{Determining Factors of Personal Financial Literacy}

This section presents further analysis of the statistically significant differences. The relationships between personal financial literacy, the characteristics of the sample and choices made about using financial services were examined. To find out if there are different factors determining the male and female students' financial literacy, the analysis was run for male and female students separately. The results of logistic regression are reported in Tables $6 \mathrm{~A}, 6 \mathrm{~B}$ and $6 \mathrm{C}$.

The tested correlation among the independent variables was low, i.e., under 0.60, which indicates that the multi-collinearity is not a problem in the current analysis.

The Forward Stepwise method was chosen, and the regression analyses were run separately for the three different samples (shown in Table 1). As suggested by the Chi-square values, the models have high explanatory power. In addition, the overall fit of the models was assessed by its ability to classify observations 
correctly. For the entire sample, $59.7 \%$ of the observations were correctly classified as compared with $50.4 \%$ of change classification; for the male students' sample, $61.0 \%$ of the observations were classified correctly compared with the change classification of $53.8 \%$; for the female students' sample, $66.0 \%$ of the observations were classified correctly compared with the change classification of $59.2 \%$.

Based on the logistic regression analysis, the results of the whole sample Table $6 \mathrm{~A}$ showed that consistent with ANOVA results presented in Table 3, the gender variable was positive and statistically significant. The results indicate that male participants are 1.8 times more likely to belong to the group of more knowledgeable about personal finance than female participants. Subsequent results suggested that students' financial literacy is related to two groups of variables: financial services and income. The coefficients of investment services were positive and statistically significant, indicating that students using these services are more likely to be more knowledgeable (in the whole sample 1.7 times) about personal finance than students without investment services. Regarding income related variables, coefficients of Income(1) and Income(2) were positive and statistically significant, indicating that those with monthly net income from 301 to 2800 euros are more likely to be more knowledgeable in personal finance compared to students with monthly net income up to 300 euros. The findings showed that the impact on financial literacy at the income over 2800 euros or with no answers from the participants was small.

The results of the logistic regression analysis of the male sample are presented in Table 6B. The coefficients of Investment services and Insurance Services were positive and statistically significant, indicating that students using these services are more likely to be more knowledgeable ( 2.1 times using Investment Services and 1.7 times using Insurance Services) about personal finance than students without these choices. Regarding income related variables, coefficients of Income(1) and Income(2) were positive and statistically significant. The value of coefficients shows that those with monthly net income from 301 to 1360 euros are (2.4 times) and those with monthly net income from 1361 to 2800 euros are (4.6 times) more likely to be more knowledgeable in personal finance than students with monthly net income up to 300 euros.

Table-6. Logistic regression results of factors influencing participants' financial literacy.

A. Model (All participants)

\begin{tabular}{l|c|c|c|c|c|c}
\hline & \multicolumn{2}{|c|}{ Step 1 } & \multicolumn{2}{c|}{ Step 2 } & \multicolumn{2}{c}{ Step 3 } \\
\cline { 2 - 7 } & $\mathbf{B}$ & $\mathbf{E x p}(\mathbf{B})$ & $\mathbf{B}$ & $\mathbf{E x p}(\mathbf{B})$ & $\mathbf{B}$ & $\mathbf{E x p}(\mathbf{B})$ \\
\hline Investment services & $0.625^{* *}$ & 1.867 & $0.611^{* *}$ & 1.843 & $0.554^{* *}$ & 1.741 \\
\hline Gender (1) & & & $0.506^{* *}$ & 1.658 & $0.578^{* *}$ & 1.782 \\
\hline Income(1) & & & & & $0.655^{* *}$ & 1.926 \\
\hline Income(2) & & & & & $1.668^{* *}$ & 5.303 \\
\hline Income(3) & & & & & 0.429 & 1.536 \\
\hline Income(4) & & & & & 0.362 & 1.436 \\
\hline Constant & -0.148 & 0.862 & $-0.522^{* *}$ & 0.594 & $-1.097^{* *}$ & 0.334 \\
\hline-2 log Likelihood & 783.557 & & 776.783 & & 763.163 & \\
\hline Chi-Square & $10.746^{* *}$ & & $17.521^{* *}$ & & $31.140^{* *}$ & \\
\hline Adjusted R & & & 0.040 & & 0.071 & \\
\hline Correct Classified & 0.025 & & 55.8 & & 59.7 & \\
\hline
\end{tabular}

B. Model (Only male participants)

\begin{tabular}{l|c|c|c|c|c|c}
\hline \multirow{2}{*}{} & \multicolumn{2}{|c|}{ Step 1 } & \multicolumn{2}{c|}{ Step 2 } & \multicolumn{2}{c}{ Step 3 } \\
\cline { 2 - 7 } & $\mathbf{B}$ & $\mathbf{E x p}(\mathbf{B})$ & $\mathbf{B}$ & $\mathbf{E x p}(\mathbf{B})$ & $\mathbf{B}$ & $\mathbf{E x p}(\mathbf{B})$ \\
\hline Investment services & $0.777^{* *}$ & 2.175 & $0.766^{* *}$ & 2.152 & $0.727^{* *}$ & 2.069 \\
\hline Insurance & & & $0.632^{* *}$ & 1.882 & $0.506^{* *}$ & 1.659 \\
\hline Income(1) & & & & & $0.873^{* *}$ & 2.395 \\
\hline Income(2) & & & & & $1.517^{*}$ & 4.556 \\
\hline Income(3) & & & & & 0.734 & 2.083 \\
\hline Income(4) & & & & & 0.775 & 2.172 \\
\hline Constant & -0.059 & 0.943 & $-0.398^{* *}$ & 0.672 & $-1.014^{* *}$ & 0.363 \\
\hline -2 log Likelihood & 575.878 & & 565.784 & & 552.059 & \\
\hline Chi-Square & $12.278^{* *}$ & & $22.371^{* *}$ & & $36.096^{* *}$ & \\
\hline Adjusted R ${ }^{2}$ & 0.038 & & 0.068 & & 0.109 & \\
\hline Correct Classified & 55.9 & & 59.6 & & 61.0 & \\
\hline
\end{tabular}


C. Model (Only female participants)

\begin{tabular}{l|c|c}
\hline \multirow{2}{*}{} & \multicolumn{2}{c}{ Step 1 } \\
\cline { 2 - 3 } & $\mathbf{B}$ & $\operatorname{Exp}(\mathbf{B})$ \\
\hline Insurance & $1.209^{*} *$ & 3.350 \\
\hline Constant & $-0.803^{* *}$ & 0.448 \\
\hline-2 log Likelihood & 187.294 & \\
\hline Chi-Square & $11.503^{* *}$ & \\
\hline Adjusted R & \\
\hline Correct Classified & 0.102 & \\
\hline \multicolumn{2}{|c}{ Chance Classification } \\
\hline Notes: *significant at the 0.05 level; ** significant at the 0.01 level or greater.
\end{tabular}

The results of the logistic regression analysis of the female sample are presented in Table $6 \mathrm{C}$. Based on the results, the only variable influencing female students' financial literacy is their choice whether they use Insurance Services. The coefficient of Insurance Services was positive and statistically significant, indicating that students using these services are more likely to be 3.4 times more knowledgeable in personal finance than students without using the Insurance Services.

In conclusion, the results support several previous research findings that there are gender differences in financial literacy and previous experiences with financial services affect the financial literacy positively.

\subsection{Comparisons and Discussion}

In this section, comparisons with earlier studies are presented.

The answers to the questions from "A simple financial literacy module" are scored and compared with study results from Finland, USA, and Estonia. Finland and USA participated in the project called Financial Literacy around the World (FLat World), coordinated by Lusardi and Mitchell.

The Finnish study conducted in 2014 was the first representative study of financial literacy in Finland. The sample (1477 observations) had respondents aged from 18 to 92 and the results were presented separately for the entire sample and for those between the ages of 25 and 65 (Kalmi \& Ruuskanen, 2018). The current study sample included $81 \%$ of students aged from 18 to 22 ; thus, the entire sample was used for the comparisons. Concerning the question of the interest rate, the difference of the correct answers provided between the students and the respondents of the first study was $24 \%$ ( $82 \%$ and $58 \%$ ). The question about inflation was answered correctly by $91 \%$ of the students and $77 \%$ of the respondents of the first study (difference 14\%). The question about risk and diversification was answered correctly by $93 \%$ of the students and $66 \%$ of the respondents of the first study (difference $27 \%$ ). In the current study, the share of respondents who answered all the questions correctly was $71 \%$ and in the Finnish first survey $36 \%$, making up more than one-third of the respondents. The results showed that students from universities of technology had particularly good general financial knowledge and the level of knowledge was higher than Finns' overall Table 7. These results were as expected; as the earlier research has shown, mathematical skills and educational attainment affect the financial literacy level (Mändmaa, 2020a; Mändmaa, 2020b).

Comparing the scores of the Finnish university students with those of a USA study (published by Lusardi (2019)), the difference in the correct answers provided to the question of the interest rate was $17 \%(82 \%$ and $65 \%)$. The question about inflation was answered correctly by $91 \%$ of students and $64 \%$ of participants from the US study and the question about risk and diversification by $93 \%$ and $52 \%$, respectively. In the current study, the share of respondents who answered all the questions correctly was $71 \%$ and in the US survey - $30 \%$. There were remarkable differences in the share of "do not know" answers, and the biggest gap was found in the answers to the question of risk and diversification (28\%). The differences were similar to the comparison made with the sample of Finnish population.

Results of the current survey are consistent with arguments reported by Lusardi and Mitchell (2011) that financial literacy is highly and positively correlated with schooling. The findings from Health and Retirement Study (HRS), a nationally representative longitudinal dataset of Americans over the age of 50, showed that respondents with educational level "college and more" had higher scores to the right answers of the three core questions (Q) (Q1 82\%; Q2 85\%; Q3 70\%) and lower DK scores (Q1 3\%; Q2 3\%; Q3 14\%) than those with educational level "less than high school" (Q1 51\%; Q2 62\%; Q3 31\% and DK Q1 17\%; Q2 $21 \%$; Q3 56\%) (Lusardi \& Mitchell, 2011).

Next, financial knowledge of Estonian and Finnish students is compared.

In the first comparison made between students (sample size 522) in Estonian higher education institutions and students (sample size 574) in Finnish universities of technology, the level and answers to the three core questions were compared.

The results Table 7 showed that Estonian students' financial knowledge was lower than that of Finnish students, especially in answers to the question of the interest rate. That could be explained by the short history of the Estonian financial markets - little experience, and by the differences in the sample - academic discipline, level of education. 
Table-7. The statistics of answers to the three core questions.

\begin{tabular}{|c|c|c|c|c|c|c|c|c|}
\hline $\begin{array}{l}\text { Description } \\
\text { A. Interest } \\
\text { rate question }\end{array}$ & $\begin{array}{c}\text { Full } \\
\text { sample } \\
\% \\
\text { EST } \\
* * *\end{array}$ & $\begin{array}{c}\text { Full } \\
\text { sample } \\
\% \\
\text { FIN }\end{array}$ & $\begin{array}{c}\text { Male } \\
\% \\
\text { EST } \\
* * *\end{array}$ & $\begin{array}{c}\text { Male } \\
\% \\
\text { FIN }\end{array}$ & $\begin{array}{c}\text { Female } \\
\% \\
\text { EST } \\
* * *\end{array}$ & $\begin{array}{c}\text { Female } \\
\% \\
\text { FIN }\end{array}$ & $\begin{array}{c}\text { Estonian } \\
\text { university } \\
\text { students' FL } \\
\text { survey } 2012 \\
\% \\
\% * *\end{array}$ & $\begin{array}{c}\text { Finnish } \\
\text { 2014 summary } \\
\text { statistics } \\
\text { (full sample) } \\
\% \\
\% *\end{array}$ \\
\hline$>110^{*}$ & 65.9 & 82.2 & 65.3 & 84.3 & 66.7 & 76.4 & 50.4 & 58.1 \\
\hline$=110$ & 16.0 & 2.6 & 16.9 & 1.6 & 14.8 & 5.4 & 36.0 & 28.0 \\
\hline$<110$ & 2.8 & 7.5 & 2.5 & 7.0 & 3.3 & 8.8 & 6.3 & 6.6 \\
\hline DK & 4.1 & 2.1 & 4.3 & 1.2 & 3.8 & 4.7 & 0 & 6.1 \\
\hline $\begin{array}{l}\text { Refused to } \\
\text { answer }\end{array}$ & 11.2 & 5.6 & 11.1 & 5.9 & 11.5 & 4.7 & 7.3 & 1.4 \\
\hline \multicolumn{3}{|c|}{ EST: Chi-Square $=0.894$ p-value $=0,971$} & \multicolumn{4}{|c|}{ FIN: Chi-Square $=14.131$ p-value $=0.007$} & $\begin{array}{l}C S=56.194 \\
P=0.000\end{array}$ & \\
\hline \multicolumn{9}{|c|}{ B. Inflation question } \\
\hline More & 2.8 & 1.6 & 3.4 & 1.9 & 1.9 & 0.7 & 5.4 & 7.1 \\
\hline $\begin{array}{l}\text { Exactly the } \\
\text { same }\end{array}$ & 0.9 & 2.4 & 1.2 & 2.6 & 0.5 & 2.0 & 2.7 & 8.8 \\
\hline Less * & 85.3 & 90.6 & 83.1 & 92.3 & 88.6 & 85.8 & 78.4 & 76.5 \\
\hline DK & 10.1 & 5.2 & 11.7 & 3.1 & 7.6 & 11.5 & 13.6 & 6.4 \\
\hline $\begin{array}{l}\text { Refused to } \\
\text { answer }\end{array}$ & 0.9 & 0.2 & 0.6 & 0.2 & 1.4 & $\mathrm{O}$ & O & 1.3 \\
\hline \multicolumn{7}{|c|}{ EST: Chi-Square $=0.270$ p-value $=0.270$} & $\begin{array}{l}C S=33.840 \\
P=0.000\end{array}$ & \\
\hline \multicolumn{9}{|c|}{ C. Risk diversification question } \\
\hline Correct (True) & 3.9 & 1.0 & 3.7 & 0.9 & 4.3 & 1.4 & 8.8 & 24.0 \\
\hline $\begin{array}{l}\text { Incorrect } \\
\text { (False)* }\end{array}$ & 79.5 & 92.5 & 78.5 & 94.4 & 81.0 & 87.2 & 79.3 & 65.8 \\
\hline DK & 14.6 & 6.4 & 15.6 & 4.7 & 12.9 & 11.5 & 11.9 & 10.2 \\
\hline $\begin{array}{l}\text { Refused to } \\
\text { answer }\end{array}$ & 2.1 & O & 2.1 & O & 1.9 & O & O & $\mathrm{O}$ \\
\hline \multicolumn{7}{|c|}{ EST: Chi-Square $=0.932$ p-value $=0.818$} & $\begin{array}{l}C S=9.669 \\
P=0.008\end{array}$ & \\
\hline \multicolumn{9}{|c|}{ D. Cross-question Consistency } \\
\hline $\begin{array}{l}\text { Interest and } \\
\text { inflation } \\
\text { correct }\end{array}$ & 59.9 & 75.4 & 58.0 & 78.6 & 62.9 & 66.2 & 28.5 & 48.0 \\
\hline \multicolumn{7}{|c|}{ EST: Chi-Square $=1.267$-value $=0.150$} & $C S=6.434$ & \\
\hline All correct & 50.7 & 71.4 & 48.8 & 75.6 & 53.8 & 59.5 & 27.2 & 35.6 \\
\hline \multicolumn{7}{|c|}{ EST: Chi-Square $=0.020$ p-value $=0.555$} & $C S=5.379$ & \\
\hline None correct & 3.0 & 1.0 & 3.1 & 0.7 & 2.9 & 2.0 & 5.2 & 7.4 \\
\hline \multicolumn{7}{|c|}{ EST: Chi-Square $=0.020$ p-value $=0.555$} & $C S=9.356$ & \\
\hline $\begin{array}{l}\text { At least one } \\
\text { DK }\end{array}$ & 18.3 & 10.1 & 18.4 & 6.3 & 18.1 & 20.9 & 22.2 & 14.0 \\
\hline \multicolumn{7}{|c|}{ EST: Chi-Square $=0.008$ p-value $=0.512$} & $C S=32.284$ & \\
\hline All DK & 0.7 & 0.3 & 0.9 & 0.2 & 0.5 & 0.7 & O & 1.4 \\
\hline \multicolumn{7}{|c|}{ EST: Chi-Square $=0.340$ p-value $=0.489$} & - & \\
\hline $\begin{array}{l}\text { Number of } \\
\text { observations }\end{array}$ & 536 & 574 & 326 & 426 & 210 & 148 & 522 & 1477 \\
\hline
\end{tabular}

The Finnish sample consisted of students from mathematics-based disciplines only on the Bachelor and Master level. The sample of the Estonian study 2012 had 28\% of students from implementing higher education studies and $47.5 \%$ of students were from non-mathematics-based disciplines. The results from Estonian 2012 study showed clear differences (10.5\% in total, $7.4 \%$ in male and $12.7 \%$ in female) in the financial literacy levels between students in Economic or Non-Economic academic disciplines. Even greater differences appeared in the overall share of mathematics-based studies. Differences in students' financial literacy in Bachelor studies were 13.6\% (male 7.6\% and female 13.6\%) and in Master studies 9.1\% (male 13.4\% and female $5.2 \%$ ) in favor of mathematics-based learning. 
The second comparison was made between Estonian (sample size 536) and Finnish (sample size 574) students in universities of technology. Comparison was made and presented separately for three core questions (from "A simple financial literacy module" with little correction), and for the results of the whole questionnaire.

The statistics for three core questions is shown in Table 7. The results showed that Estonian students' financial knowledge was slightly lower than Finnish students', except the amount of Estonian female participants' right answers about inflation questions, which was $3 \%$ higher compared to neighbor country female students' answers.

The share of "do not know" (DK) answers among Finnish students was lower than that in Estonian students in all samples, and much lower compared to male students' answers. This could be understood as Finnish male students' higher self-confidence in financial knowledge.

In addition, the current study of Finnish students showed the differences between female and male students' responses and that male students had 6 to $8 \%$ higher scores, which is consistent with several earlier studies results (Atkinson et al., 2006; Atkinson \& Messy, 2012; Bucher-Koenen \& Lusardi, 2011; BucherKoenen et al., 2017; Chen \& Volpe, 1998; Chen \& Volpe, 2002; Fonseca et al., 2012; Goldsmith \& Goldsmith, 1997; Goldsmith \& Goldsmith, 2006; Kalmi \& Ruuskanen, 2018; Lusardi et al., 2010; Mändmaa, 2019a; Mändmaa, 2019b).

Differences between Estonian and Finnish students' financial knowledge were small. The results of the whole questionnaire showed that students' financial literacy is at Medium level - an average score of correct answers among Estonians was $68 \%$ and among Finns $74 \%$, whereas female students answered $69 \%$ of the questions and $72 \%$ of questions correctly, respectively and the male students $67 \%$ and $74 \%$ of the questions correctly, respectively.

Mean percentage of correct responses by gender, and results of ANOVA are reported in the Appendix and Table 2. The lowest scores in the answers to the question were acquired in both countries in: "If the interest rate rises, the prices of a Treasury bond will: increase; decrease; remain the same; impossible to predict; do not know." This question needs more specific knowledge or experience, and the results were as expected, as respondents were university students mostly in their young age (18 to 22), which means they were in very early stage of their financial life cycle.

There were gender differences found in students' financial literacy Figures 1 and 2. Female students in the Estonian survey had slightly higher financial literacy level than male students and Finnish students' results were vice versa.

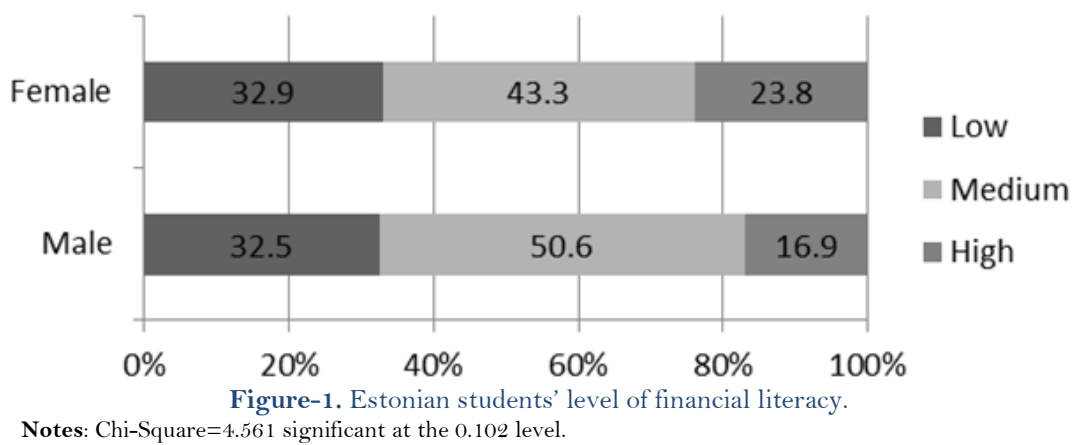

Author's own preparation based on Estonian university students' financial literacy study from year 2015.



Notes: Chi-Square $=7.656$ significant at the 0.022 level. 
The gender differences in the results of the two countries could be explained by differences in political history. The former Communist societies were much more egalitarian with respect to gender roles and as Estonia was part of Soviet Union for 51 years, that could explain female slightly higher financial knowledge. Researchers have argued in earlier studies that gender differences in financial literacy in former Communist societies could be interpreted as prime facile evidence that as financial markets develop, women are left behind in terms of financial knowledge (Bucher-Koenen et al., 2017).

The results of regression analyses showed some differences in factors influencing students' financial literacy. In the study of Estonian students, Academic Discipline, Level of Education, Age and Nationality were found as statistically significant factors, which were not significant in the Finnish students' study. Previous experience in using financial services was a significant factor for the financial literacy of both countries' students. Findings showed that the most important factor in the Finnish study was income, which had no significant impact on Estonian students' financial literacy.

The differences pointed out above could be caused by the lower standard of living in Estonia, a shorter history of financial market, deficiency of financial education and missing skills of parents to passing on the financial knowledge to children.

In addition, comparison of the results of the current study with the findings of the study conducted among students in Estonian higher educational institutions in 2012 reveals a notable impact of an academic discipline. Students from academic disciplines with mathematics-based studies showed higher financial literacy scores $(68 \%$ and $57 \%)$ than students from other disciplines (Mändmaa, 2019a; Mändmaa, 2019b) while in the current study, the sample consisted only of students with mathematics-based curriculums and the results demonstrate no influence of the academic discipline on the students' financial literacy Table 3.

\section{Conclusions}

The main goal of this study was to find out the needs and gaps in financial education using the assessment and comparison of students' financial literacy to develop the field.

This study examined the knowledge of 574 students from two universities in Finland to assess the students' financial literacy level, find out the factors influencing the knowledge of personal finance and to compare the findings with similar studies.

The study includes a comparison with studies that were conducted in the neighbouring country, Estonia, among university students in 2012 (522 participants) and 2015 (536 participants).

Among Finns, the level of financial literacy was found to be relatively high. Using the scale Low-MediumHigh, the students' financial knowledge in both countries (studies from 2015/2016) was assessed to the medium level, but Finnish results were slightly higher (FIN 74\% and EST 68\%) and there occurred some gender differences. Among Finnish students, males had higher financial literacy scores than females (male $74 \%$ and female $72 \%$ ), but Estonian female students' average score was a little higher than male students' score (female $69 \%$ and male $67 \%$ ). By far the weakest answers to the questions were about homeowner's insurance and about connection between interest rate changes and treasury bonds prices, where only $15 \%$ and $18 \%$ of the participants accordingly gave correct answers.

Participants' choices about using the financial services were analyzed and the results showed that in general, the participants with higher level of financial literacy used financial services more than participants with lower financial literacy level. $17 \%$ of the participants were users of credit cards, which is not an amount to be worried.

The responses about planning habits of financial affairs showed that most preferable planning period was one month, picked by $38 \%$ of students; $13 \%$ of students planned their financial affairs to several years and less than $1 \%$ until retirement. In terms of long-term planning, the higher financial literacy level generally was related to a longer planning period. The share of students who see no need to plan was on average $3 \%$.

Based on the results of regression analyses, the factors influencing students' financial knowledge were gender, income, and experience in using insurance and investment services.

Although Estonians and Finns are representatives of two related nations, the differences in recent history have left their marks. Comparison of the students in the same academic disciplines, i.e., in the current case, in the mathematics-based technological disciplines, revealed notable financial knowledge of Estonian female students. However, the results of students from different academic disciplines (study from 2012) showed a remarkable gap in students' financial literacy levels, acknowledging higher knowledge of male students.

These results confirm the arguments and enable drawing the following conclusions:

- As financial markets develop, women are left behind in terms of financial knowledge, as presented in an earlier study in Germany and in the comparison between Estonian and Finnish students' financial literacy in the current study.

- The better the skills in mathematics, the better the results in financial literacy, which was confirmed by the comparison with the survey results conducted in Estonia in 2012 and 2015.

- In the financial literacy, female students have weaker results because of weaker mathematics skills also, as it is argued in the earlier research - female students prefer non-math-based subjects. 
On the whole, incompetency in financial literacy will limit students - the creators of our future - ability to make informed financial decisions and pass on necessary knowledge to descendants.

When individuals cannot manage their finances, it becomes a problem for the society (Chen \& Volpe, 1998).

The findings of this study suggest that students' financial literacy needs improvement especially in the conditions of our rapidly changing financial markets. Moreover, it is necessary to improve the teaching of mathematics that in some levels could be taught to males and females separately and universities could offer optional mathematics courses to prepare better understanding of managing personal finance and to reduce the subconscious fear to the subject - mathematics.

The finding that students prefer short-term planning to long-term planning is of equal importance, which gives another goal for educators - to teach young people to understand responsibility of own future. Furthermore, the understanding about financial terminology and the ability to understand the market alone do not pay the bills, neither today nor at retirement - there must be some reserves to ensure sustainability.

This study has its limits, as the quantitative research methods were used there is a lack of specific suggestions for promoting personal financial education, including students' visions - needs. That highlights the need to continue the research with qualitative methods - interviews.

\section{References}

Altintas, K. M. (2011). The dynamics of financial literacy within the framework of personal finance: An analysis among Turkish University Students. African Journal of Business Management, 5(26), 10483 - 10491.

Atkinson, A., McKay, S., Kempson, E., \& Collard, S. (2006). Levels of financial capability in the UK: Results of a baseline survey (Vol. 150): University of Bristol: Personal Finance Research Centre.

Atkinson, A., \& Messy, F. (2012). Measuring financial literacy: Results of the OECD / International Network on Financial Education (INFE) Pilot study. OECD Working Papers on Finance, Insurance and Private Pensions, No 15, OECD Publishing, Paris.

Bucher-Koenen, T., \& Lusardi, A. (2011). Financial literacy and retirement planning in Germany. Journal of Pension Economics and Finance, 1O(4), 565-584.Available at: https://doi.org/10.1017/S1474747211000485.

Bucher-Koenen, T., Lusardi, A., Alesi, R., \& Van Rooij, M. (2017). How financially literate are women? An overview and new insights. Journal of Consumer Affairs, Wiley Blackwell, 51(2), 255-283.Available at: https://doi.org/10.3386/w20793.

Chen, H., \& Volpe, R. P. (1998). An analysis of personal financial literacy among college students. Financial Services Revierw, 7(2), 107-128.Available at: https://doi.org/10.1016/S1057-0810(99)80006-7.

Chen, H., \& Volpe, R. P. (2002). Gender differences in personal financial literacy among college students. Financial Services Review, 1 1(3), 289-307.

Cole, S. A., Paulson, A. L., \& Shastry, G. K. (2012). Smart Money: The effect of education on financial behavior. Harvard Business School Finance Working Paper No. 09-071.

FactsMaps. (n.d). PISA 2015 Worldwide ranking - average score of math, science and reading. Retrieced from: http://factsmaps.com/pisa-worldwide-ranking-average-score-of-math-science-reading/.

Fonseca, R., Mullen, K., Zamarro, G., \& Zissimopoulos, J. (2012). What explains the gender gap in financial literacy? The role of household decision-making. The Journal of Consumer Affairs, 46(1), 90-106.

Goldsmith, E. B., \& Goldsmith, R. E. (1997). Gender differences in perceived and real knowledge of financial investments. Psychological Report, 80, 236-238.Available at: https://doi.org/10.2466/pro.1997.80.1.236.

Goldsmith, E. B., \& Goldsmith, R. E. (2006). The effects of investment education on gender differences in financial knowledge. Journal of Personal Finance, 5(2), 55-69.

Kalmi, P., \& Ruuskanen, O. P. (2018). Financial literacy and retirement planning in Finland. Journal of Pension Economics and Finance, 17(3), 335-362.Available at: https://doi.org/10.1017/S1474747217000270.

Lusardi, A., \& Mitchell, O. S. (2006). Financial literacy and planning: Implications for retirement wellbeing. Working Paper, Pension Research Council, Wharton School, University of Pennsylvania.

Lusardi, A., \& Tufano, P. (2009). Debt literacy, financial experiences, and over indebtedness. NBER Working Paper, No 14808

Lusardi, A., Mitchell, O. S., \& Curto, V. (2010). Financial literacy among the young. Journal of Consumer Affairs, Wiley Blackwell, 44, 358-380.Available at: https://doi.org/10.1111/j.1745-6606.2010.01173.x.

Lusardi, A., \& Mitchell, O. S. (2011). Financial literacy and planning: Implications for retirement wellbeing. National Bureau Of Economic Research, Working Paper No 17078.

Lusardi, A. (2017). Lusardi on financial literacy levels: "We need robust interventions". House of Finance, Stocholm. Retrieved from: https://www.hhs.se/en/houseoffinance/research/featured-topics/2017/lusardi-on-financialliteracy-levels-we-need-robust-interventions/.

Lusardi, A. (2019). Financial literacy and the need for financial education: evidence and implications. Swiss Journal of Economics and Statistics, 155(1), 1.

Mandell, L. (2008). The financial literacy of young american adults. Results of the 2008 National JumpStart Coalition Survey of High School Seniors and College Students. JumpStart Coalition for Personal Financial Literacy, Washington DC. Retrieved from: https://www.stockmarketgame.org/assets/pdf/2008\%20JumpStart\%20Financial\%20Literacy\%20Survey.pdf.

Mändmaa, S. (2019a). Financial literacy - what and why should we improve. Eurasian Journal of Social Sciences, 7(2), 12 28.Available at: https://doi.org/10.15604/ejss.2019.07.02.002.

Mändmaa, S. (2019b). Analyzing the factors influencing university students' financial literacy. International Journal for Innovation Education and Research, 7(7), 465-497.Available at: https://doi.org/10.3 1686/ijier.Vol7.Iss7.1628. 
Mändmaa, S. (2020a). Empirical study on personal financial literacy of university students for develop the financial education. International Journal of Business and Applied Social Science, 6(6), 8-25.Available at: https://doi.org/10.33642/ijbass.v6n6p2.

Mändmaa, S. (2020b). Personal financial literacy among university students studying engineering. International Journal for Innovation Education and Research, 8(8), 669-692.Available at: https://doi.org/10.31686/ijier.vol8.iss8.2575.

Monticone, C. (2010). How much does wealth matter in the acquisition of financial literacy? Journal of Consumer Affairs, 44(2), 403 - 422.Available at: https://doi.org/10.1111/j.1745-6606.2010.01175.x.

OECD. (2006). Improving financial literacy: Analysis of issues and policies. Financial Market Trends 2005/2,111-123. Retrieved from: https://dx.doi.org/10.1787/fmt-v2005-art11-en.

OECD. (2014). PISA 2012 results: Students and money: Financial Literacy Skills for the 21st Century (Vol. 6). Paris: PISA, OECD Publishing.

Pires, V., \& Quelhas, A. P. (2015). Financial literacy among the higher education students: Empirical Evidence for the portuguese case. Portuguese Journal of Finance, Management and Accounting, 1(1), 84-103.Available at: http://usisjournal.isvouga.pt/index.php/PJFMA.

Reed, M. (2008). Report student debt and the class of 2007. The project on student debt. Retrieved from: http://ticas.org/sites/default/files/pub_files/classof2007.pdf. [Accessed 20 November 2012].

Appendix Mean percentages of correct responses by gender, and the results of ANOVA

\begin{tabular}{|c|c|c|c|c|c|c|c|c|c|c|}
\hline \multirow{4}{*}{$\begin{array}{l}\text { Brief description of } \\
\text { the questions }\end{array}$} & \multicolumn{10}{|c|}{ Level of Personal Financial Literacy } \\
\hline & \multicolumn{3}{|l|}{ Low } & \multicolumn{3}{|c|}{ Medium } & \multicolumn{3}{|c|}{ High } & \multirow{3}{*}{$\begin{array}{c}\text { Total } \\
\% \\
\end{array}$} \\
\hline & \multicolumn{3}{|c|}{ Below 60\% } & \multicolumn{3}{|c|}{$60-79 \%$} & \multicolumn{3}{|c|}{ Over $80 \%$} & \\
\hline & $\mathbf{M}$ & $\mathbf{F}$ & F test & $\mathbf{M}$ & $\mathbf{F}$ & F test & $\mathbf{M}$ & $\mathbf{F}$ & F test & \\
\hline \multicolumn{11}{|c|}{ I General Personal finance knowledge } \\
\hline $\begin{array}{l}\text { 1. Personal financial } \\
\text { literacy }\end{array}$ & & & & 73.9 & 70.0 & 0.983 & & & & 72.4 \\
\hline 2. Asset liquidity & 41.1 & 48.6 & 2.895 & & & & & & & 44 \\
\hline $\begin{array}{l}\text { 3. Definition of } \\
\text { inflation }\end{array}$ & & & & 71.8 & 77.1 & 1.904 & & & & 73.9 \\
\hline $\begin{array}{l}4 . \quad \text { Time value of } \\
\text { money }\end{array}$ & & & & & & & 79.4 & 83.3 & 1.250 & 81 \\
\hline $\begin{array}{l}\text { 5. Interest paid on } \\
\text { loan }\end{array}$ & & & & & & & 95.7 & 96.2 & 0.076 & 95.9 \\
\hline $\begin{array}{l}\text { 6. Legal requirement } \\
\text { for apartment lease }\end{array}$ & & & & 66.9 & 70.0 & 0.574 & & & & 68.1 \\
\hline $\begin{array}{l}\text { 7. Change in the } \\
\text { purchasing power of } \\
\text { money }\end{array}$ & 59.5 & 50.9 & $3.811^{*}$ & & & & & & & 56.2 \\
\hline 8. Discount valuation & & & & & & & 97.8 & 96.7 & 0.705 & 97.4 \\
\hline $\begin{array}{l}\text { Mean } \\
\text { responses for the I } \\
\text { section }\end{array}$ & & & & 72.7 & 73.5 & 0.332 & & & & 73 \\
\hline
\end{tabular}

II Saving, borrowing, insurance and investments

\begin{tabular}{|c|c|c|c|c|c|c|c|c|c|c|}
\hline $\begin{array}{l}\text { 9. Appropriate saving } \\
\text { place }\end{array}$ & & & & 76.1 & 76.7 & 0,025 & & & & 76.3 \\
\hline $\begin{array}{l}\text { 10. Calculation of } \\
\text { interest plus principle }\end{array}$ & & & & & & & 89.3 & 90.5 & 0.203 & 89.7 \\
\hline 11. Compound interest & & & & 65.3 & 66.7 & 0.100 & & & & 65.9 \\
\hline $\begin{array}{l}\text { 12. Purchasing power } \\
\text { assessment }\end{array}$ & & & & & & & 83.1 & 88.6 & 3.016 & 85.3 \\
\hline $\begin{array}{l}\text { 13. Monthly payments } \\
\text { of mortgage }\end{array}$ & & & & 68.1 & 70.5 & 0.337 & & & & 69 \\
\hline 14. Interest of loan & 53.4 & 56.7 & 0.557 & & & & & & & 54.7 \\
\hline $\begin{array}{lll}15 . \quad \text { Loan } & \text { co-sing } \\
\text { consequences }\end{array}$ & & & & 59.5 & 66.2 & 2.425 & & & & 62.1 \\
\hline $\begin{array}{l}\text { 16. The interest rate } \\
\text { evaluation }\end{array}$ & & & & & & & 89.0 & 91.0 & 0.551 & 89.7 \\
\hline $\begin{array}{l}\text { 17. Understanding the } \\
\text { content of insurance }\end{array}$ & 35.6 & 38.6 & 0.489 & & & & & & & 36.7 \\
\hline $\begin{array}{l}18 . \quad \text { Homeowners' } \\
\text { insurance }\end{array}$ & 33.1 & 43.3 & $5.737^{*}$ & & & & & & & 37.1 \\
\hline
\end{tabular}




\begin{tabular}{l|ll|ll|l|l}
\hline $\begin{array}{l}19 . \quad \text { Revenue of } \\
\text { different Interest } \\
\text { calculation }\end{array}$ & 46.9 49.5 0.343 & & & & & \\
\end{tabular}

Notes: "M" - the average scores of male participants; "F" - the average scores of female participants.

F test - value of F-Statistic; * significant at the 0.05 level.

Source: Author's own preparation based on Estonian university students' financial literacy study, published by Mändmaa... (2020b)). 